\title{
Ameliorating Effects of Bone Marrow Transplantation and Zinc Supplementation on Physiological and Inmunological Changes in $\gamma$-Irradiated Rats.
}

\author{
Omaima M. Ashry*, Maha G. Soliman**, Mervat A.E. Ahmed ** and Yasmine \\ H. Abd El-Naby** \\ * Radiation Biology Department, National Center for Radiation Research and \\ Technology (NCRRT), P.O. Box 29 Nasr City and ** Zoology Department, Faculty of \\ Science, Al-Azhar University for Girls,Egypt.
}

\begin{abstract}
$\mathrm{T}$ he present study was carried out to determine the prophylactic impact of zinc sulphate administration to irradiated rats treated with bone marrow transplantation (BMT) as indicated by the hematological and immunologic response as well as oxidative stress.Rats were injected orally with zinc sulphate, $10 \mathrm{mg} / \mathrm{Kg}$ body wt, daily for 2 weeks before whole body $5 \mathrm{~Gy}$ gamma irradiation and intravenous injection )i.v.) of bone marrow cells, one hour post irradiation. The results revealed a significant decrease in red blood cells (RBC), white blood cells (WBC), glutathione (GSH) and zinc superoxide dismutase (Zn /SOD), splenocyte count as well as bone marrow lymphocyte count and viability of irradiated rats. Regarding immunological data: tumor necrosis factor alpha (TNF- $\alpha$ ) and interleukin 2 (IL-2) recorded a significant decrease while interleukin 6 (IL-6) and lipid peroxidation product (MDA) in the serum and spleen were conversely elevated. Zn supplementation before irradiation and BMT and showed significant decrease of serum and tissue MDA compared to the irradiated group. Lymphocytes, bone marrow viability percentage, splenocytes percentage, IL-2, IL-6 and GSH were significantly elevated compared to irradiated group. Conclusion: Protection with $\mathrm{Zn}$, enforcing significant innate response, could trigger and augment adaptive immune response by BMT which suggests its use to protect against radiation hazards.
\end{abstract}

Keywords: BMT; gamma irradiation; zinc sulphate; immunologic response. Running title: Bone marrow transplantation, radiation protection

\section{Introduction}

Acute effects of radiation include hematopoietic cell loss, immune suppression, and potential injury to other sites such as the lung, kidney and central nervous system (Augustine et al. 2005). Irradiation ruptures adult tissue homeostasis, inducing radiation syndromes, described in hematopoietic tissue (for doses higher than $2 \mathrm{~Gy}$, total body irradiation). It appears that a major mechanism of these syndromes is a rapid and massive cell death in stem and/or progenitor cell populations, which can follow either apoptotic or necrotic pathways (Harfouche and Martin, 2010). Ionizing radiation works by damaging the DNA of exposed tissue leading to cellular death (Pourhomayoun et al., 2014).

It has been anticipated that a successful role played by bone marrow transplants against deleterious effect of radiation exposure would certainly be used for tissue repairs (Youn et al., 2010). After several weeks of growth in bone marrow, expansion of haematopoeitic stem

Corresponding auther : omamashry@yahoo.com 
cells and their progeny is sufficient to reinitiate the immune system (Gérard,2001).

Zinc $(\mathrm{Zn})$ is an essential trace element that plays structural, regulatory and catalytic roles in the body and it is necessary for a number of immune functions, including $\mathrm{T}$ lymphocyte activity. A deficiency of zinc affects a number of aspects of innate and adaptive immunity (Haase and Rink, 2009). Zinc is essentially required in humans and animals for many physiological functions, including immune and antioxidant function, growth and reproduction (Sun et al., 2005). It protects various membrane systems from peroxidative damages induced by heavy metals and high oxygen tension and stabilize the membrane perturbations. It has protective effects against radiation hazards (Azab et al., 2004).

This work aims to investigate the effect of boosting of immune response, by zinc administration before irradiation followed by bone marrow transplantation (BMT) on immunological recovery and oxidative stress induced by gamma irradiation.

\section{Materials and Methods}

Mature male albino rats of pure strain Rattus rattus $(110-130 \mathrm{~g})$ obtained from the animal house of the National Center for Radiation Research and Technology (NCRRT), Atomic Energy Authority, Egypt were used in the present study. Rats were kept under normal conditions, temperature 18$22^{\circ} \mathrm{C}$, allowed free access to rat pellet and drinking water. Animals were acclimatized to laboratory conditions before the onset of the experiment. All animal treatments were conducted according to the Ethics Committee of the National Research Centre in accordance with international ethical considerations and conformed to the Guide for the Care and Use of Laboratory Animals published by the US National Institutes of Health (HN publication No. 85-23, 1996).

\section{Irradiation Facility}

Whole body irradiation was performed using Gamma Cell - 40 (137 Cesium) biological irradiator manufactured by Canada Ltd, Ottawa, Ontario, Canada, located at NCRRT. Animals were irradiated at an acute single dose of $5 \mathrm{~Gy}$ at a dose rate of $0.49 \mathrm{~Gy} / \mathrm{min}$.

Bone Marrow Transplantation
Donors and recipients were chosen of the same inbred strain, brother to brother (syngenic). Femur bones were dissected out and cleaned. The ends of the bones were chipped by a bone nibbling forceps and the marrow was blown out of the femur into isotonic solution under sterilized conditions inside a laminar flow cabinet. The marrow was collected into a sterile container surrounded by ice cubes, and mixed by drawing and expelling it several times from a syringe without needle in order to avoid mechanical damage to the cells. Femur marrow cells (1x 10 7) (Chen et al.2007) were injected intravenously (i.v.) to each rat, 1 hour after irradiation (Sredini et al., 1992).

Zinc Supplementation: Zinc sulfate (from Sigma Alderich Chemical Co.St Louis, Mo, USA) was dissolved in sterile water to achieve a zinc stock solution of $80 \mathrm{mM}$, which was then sterile filtered. Rats were injected with 10mg / Kg body weight (oral injection) as a single daily dose for 14 successive days before irradiation (Roosen et al., 1994).

Animals were randomly assigned into 6 groups: 1.Control rats received distilled water throughout the experiment $(\mathrm{C}) .2$. Rats injected with BMT cells through the caudal vein (CBM).3. Rats received orally $10 \mathrm{mg} / \mathrm{Kg}$ body weight of zinc sulphate as a single daily dose for 14 successive days (CZn). 4. Rats exposed to $5 \mathrm{~Gy}$ whole body gamma rays (R). 5.Rats exposed to 5Gy gamma rays and treated with BMT one hour after irradiation $(\mathrm{R}+$ $\mathrm{BM}$ ).6. Rats received 10mg / Kg body weight of zinc sulphate for 14 successive days before $5 \mathrm{~Gy}$ irradiation $(\mathrm{R}+\mathrm{Zn})$. 7. Rats received orally $10 \mathrm{mg} /$ $\mathrm{Kg}$ body weight of zinc sulphate as a single daily dose for 14 successive days before irradiation and treated with BMT one hour after irradiation $(\mathrm{R}+\mathrm{BM}+\mathrm{Zn})$. All animal groups were sacrificed after 14 days from treatment, irradiation or preirradiation treatment and BMT.

Groups of ten rats were anaesthetized with ether obtained from SDFCL SD Fine Chemical Limited, Industrial State- 248, Mumbai, India. Blood was collected by heart puncture. Part of the blood was placed on ethylene diamine tetra acetic acid (EDTA) from Sigma Aldrich Chemical Co. St Louis, MO, USA, for haematological analysis. Red blood cells (RBC), white blood cells (WBC) count were performed in a hemocytometer using

Egypt. J. Rad. Sci. Applic., Vol. 30, No.1(2017) 
standard procedures and lymphocytes were determined according to Dacie and Lewis (1993). All chemicals and reagents were pure chemical materials from Sigma-Aldrich. Blood reduced GSH and $\mathrm{Zn} / \mathrm{SOD}$ contents ware measured according to Beutler et al. (1963) and Yoshioka et al. (1979) respectively. Serum was separated by blood centrifugation and stored frozen until assayed. Estimation of serum MDA was performed according to (Yoshioka et al., 1979). Eliza kit from Aviscera Bioscience Inc.234 Walsh Ave, CA 95051 USA was used to determine IL-2 according to Chan and Perlstein, (1987). IL-6 was determined using the kit from Kamya Biomedical Company, Gateway, Seatle, USA according to Kaminska et al. (2000) and TNF- $\alpha$ concentrations were determined by ELISA kit fromViva systems Biology, San Diego,California USA according to and Aramachi, (1989). The spleen was dissected out, washed in saline and dried on filter paper. A known weight of spleen was homogenized in $0.15 \mathrm{KCl}$ to obtain $10 \%$ tissue homogenate using Teflon homogenizer (Glas-Col,Terre Haute,Ind., USA).The homogenates were centrifuged at $10,000 \mathrm{~g}$ for $15 \mathrm{~min}$ using refrigerated centrifuge (K3 Centurion Scientific Ltd, London, UK). Aliquots of supernatents were separated to estimate MDA (Yoshioka et al., 1979).

Determination of viable BM cell percentage: A uniform cell suspension of BM was prepared by dilution in saline solution (9\%). A haemocytometer was used for counting BM cells using $100 \mathrm{x}$ eye piece of objective lens. BM cell viability was determined using trypan blue, where only dead cells absorbed the dye, Esser et al. (2001). \%viability $=$ viable cells $/$ total no per femur X100.

BM lymphocytes percentage: BM smears were prepared on microscope slides, stained with Gimsa stain. A total of 500 cells were counted from each slide and the percentage of lymphocytes was determined in relation to the total count according to the method of Sinai et al. (1978).

Determination of splenocytes percentage: A uniform cell suspension of spleen was prepared in saline solution. A haemocytometer was used for counting spleen cells using 100x eye piece objective microscope lens. Cell viability was determined using trypan blue to distinguish viable and non viable cells, according to and Takabatake et al. (1997).
The results were analyzed using one way analysis of variance (ANOVA) followed by Duncan's test according to Steel and Torrie (1980).

\section{Results}

TABLE 1. Effect of BMT and Zn supplementation on some blood parameters in irradiated and non-irradiated rats.

\begin{tabular}{|cccc|}
\hline Groups & $\begin{array}{c}\text { RBCs } \\
\left(\mathbf{1 0} / \mathbf{m m}^{3}\right)\end{array}$ & $\begin{array}{c}\text { WBCs } \\
\mathbf{( 1 0 ^ { 3 } /} \\
\left.\mathbf{m m}^{3}\right)\end{array}$ & $\begin{array}{c}\text { Lymphocytes } \\
\mathbf{( \% )}\end{array}$ \\
\hline Control & $7.32 \pm 0.38$ & $6.04 \pm 0.57$ & $44.8 \pm 0.37$ \\
\hline $\mathrm{CBM}$ & $6.92 \pm 0.31$ & $5.14 \pm 0.42$ & $\begin{array}{c}37.4 \pm 0.73 \\
\mathrm{c}\end{array}$ \\
\hline $\mathrm{CZn}$ & $6.74 \pm 0.43$ & $6.14 \pm 0.44$ & $\begin{array}{c}38.6 \pm 0.6 \\
\mathrm{c}\end{array}$ \\
\hline $\mathrm{R}$ & $\begin{array}{c}5 \pm 0.3 \\
\mathrm{c}\end{array}$ & $\begin{array}{c}2.52 \pm 0.46 \\
\mathrm{c}\end{array}$ & $\begin{array}{c}22.2 \pm 0.86 \\
\mathrm{c}\end{array}$ \\
\hline $\mathrm{R}+\mathrm{BM}$ & $\begin{array}{c}6.18 \pm 0.27 \\
\mathrm{r}\end{array}$ & $\begin{array}{c}3.52 \pm 0.45 \\
\mathrm{c}\end{array}$ & $\begin{array}{c}31.4 \pm 0.25 \\
\mathrm{cr}\end{array}$ \\
\hline $\mathrm{R}+\mathrm{Zn}$ & $\begin{array}{c}6.32 \pm 0.46 \\
\mathrm{r}\end{array}$ & $\begin{array}{c}5.14 \pm 0.31 \\
\mathrm{r}\end{array}$ & $\begin{array}{c}37 \pm 0.35 \\
\mathrm{cr}\end{array}$ \\
\hline $\mathrm{R}+\mathrm{BM}$ & $\begin{array}{c}6.54 \pm 0.44 \\
+\mathrm{Zn}\end{array}$ & $\begin{array}{c}4.66 \pm 0.73 \\
\mathrm{r}\end{array}$ & $\begin{array}{c}39.4 \pm 0.5 \\
\mathrm{cr}\end{array}$ \\
\hline
\end{tabular}

Values are expressed as mean $\pm \mathrm{SE}$.

c: Significant difference compared to control. $r$ : Significant difference compared to R group.

TABLE 2. Effect of BMT and Zn supplementation on $\mathrm{BM}$ percentage and viability also splenocyte percentage in irradiated and non-irradiated rats.

\begin{tabular}{|c|c|c|c|}
\hline Groups & $\begin{array}{c}\text { Bone } \\
\text { marrow } \\
\text { lymphocyte } \\
\text { count } \\
(\%)\end{array}$ & $\begin{array}{c}\text { Viable bone } \\
\text { marrow } \\
\text { count } \\
(\%)\end{array}$ & $\begin{array}{c}\text { Splenocyte } \\
(\%)\end{array}$ \\
\hline Control & $20.4 \pm 0.5$ & $66.4 \pm 0.5$ & $77 \pm 0.7$ \\
\hline CBM & $21 \pm 0.7$ & $65 \pm 0.7$ & $74.6 \pm 1.2$ \\
\hline $\mathrm{CZn}$ & $20 \pm 0.54$ & $64.4 \pm 0.81$ & $77.2 \pm 0.86$ \\
\hline $\mathrm{R}$ & $\begin{array}{c}13.4 \pm 0.5 \\
\mathrm{c}\end{array}$ & $\begin{array}{c}41.2 \pm 0.58 \\
\mathrm{c}\end{array}$ & $\begin{array}{c}44.4 \pm 1.91 \\
c\end{array}$ \\
\hline $\mathrm{R}+\mathrm{BM}$ & $\begin{array}{c}16.16 \pm 0.60 \\
\mathrm{cr}\end{array}$ & $\begin{array}{c}50.4 \pm 0.51 \\
\mathrm{cr}\end{array}$ & $\begin{array}{c}52.4 \pm 0.81 \\
\mathrm{cr}\end{array}$ \\
\hline $\mathrm{R}+\mathrm{Zn}$ & $\begin{array}{c}13.33 \pm 0.80 \\
\mathrm{c} \mathrm{r}\end{array}$ & $\begin{array}{c}52.6 \pm 0.4 \\
\mathrm{c} \mathrm{r}\end{array}$ & $\begin{array}{c}52.8 \pm 0.86 \\
\mathrm{c} \mathrm{r}\end{array}$ \\
\hline $\begin{array}{c}\mathrm{R}+\mathrm{BM} \\
\quad+\mathrm{Zn}\end{array}$ & $\begin{array}{c}18 \pm 0.31 \\
\text { c r }\end{array}$ & $\begin{array}{c}67.8 \pm 0.37 \\
\text { c r }\end{array}$ & $\begin{array}{c}57 \pm 0.54 \\
\text { c r }\end{array}$ \\
\hline
\end{tabular}

Exposure of animals to 5Gy gamma radiation induced a significant $(\mathrm{P}<0.05)$ drop of $\mathrm{RBC}$, WBC and lymphocytes (Table 1) as well as $\mathrm{BM}$ percentage, BM viability also splenocyte percentage (Table 2). BMT together with irradiation showed a significant elevation of $\mathrm{RBC}$, lymphocytes, as well as BM and splenocytes percentage compared to irradiated group. The same trend was observed by $\mathrm{Zn}$ supplementation 
TABLE 3. Effect of BMT and Zn supplementation on IL-2, IL-6 and TNF- $\alpha$ in irradiated and non-irradiated rats.

\begin{tabular}{|c|c|c|c|}
\hline Groups & $\begin{array}{c}\text { IL-2 } \\
(\mathrm{pg} / \mathrm{ml})\end{array}$ & $\begin{array}{c}\text { IL-6 } \\
\text { (pg/ml) }\end{array}$ & $\begin{array}{c}\text { TNF- } \alpha \\
(\mathrm{pg} / \mathrm{ml})\end{array}$ \\
\hline Control & $165.8 \pm 1.24$ & $164.4 \pm 1.8$ & $353.2 \pm 2.15$ \\
\hline $\mathrm{CBM}$ & $\begin{array}{c}178 \pm 1.41 \\
\mathrm{c} \\
\end{array}$ & $\begin{array}{c}172.8 \pm 2.81 \\
\mathrm{c} \\
\end{array}$ & $\begin{array}{c}344 \pm 1.76 \\
\mathrm{c}\end{array}$ \\
\hline $\mathrm{CZn}$ & $162.4 \pm 1.02$ & $167.2 \pm 2.59$ & $348.2 \pm 1.06$ \\
\hline $\mathrm{R}$ & $\begin{array}{c}118.6 \pm 1.36 \\
\mathrm{c}\end{array}$ & $\begin{array}{c}301.8 \pm 2.51 \\
\mathrm{c}\end{array}$ & $185 \pm 1.7$ \\
\hline $\begin{array}{l}\mathrm{R}+ \\
\mathrm{BM}\end{array}$ & $\begin{array}{c}108.2 \pm 1.39 \\
\mathrm{cr}\end{array}$ & $\begin{array}{c}256 \pm 2.38 \\
\mathrm{cr} \\
\end{array}$ & $\begin{array}{c}254 \pm 1 \\
\mathrm{cr}\end{array}$ \\
\hline $\mathrm{R}+\mathrm{Zn}$ & $134 \pm 1.41$ & $236.2 \pm 2.63$ & $219.6 \pm 1.32$ \\
\hline $\begin{array}{c}\mathrm{R}+\mathrm{BM} \\
+\mathrm{Zn} \\
\end{array}$ & $\begin{array}{c}137.6 \pm 1.36 \\
\mathrm{cr}\end{array}$ & $\begin{array}{c}238 \pm 1.51 \\
\mathrm{cr}\end{array}$ & $\begin{array}{c}235.2 \pm 1.77 \\
\mathrm{cr}\end{array}$ \\
\hline
\end{tabular}

Values are expressed as mean $\pm \mathrm{SE}$.

c: Significant difference compared to control. r: Significant difference compared to R group.

before irradiation compared to irradiated group. Protection with $\mathrm{Zn}$ to irradiated animals receiving BMT elevated RBCs, lymphocytes, $\mathrm{BM}$ percentage and viability and also splenocyte percentage $(\mathrm{P}<0.05)$ compared to irradiation group

CBM alone induced significant elevations of IL- 1 and IL-6, while TNF- $\alpha$ was decreased. Gamma irradiation (5Gy) induced a significant decrease of serum IL-2 and TNF- $\alpha$ values $(\mathrm{P}<0.05)$

TABLE 4. Effect of BMT and Zn supplementation on blood GSH and ZN/SOD, serum MDA and spleen MDA in irradiated and non-irradiated rats.

\begin{tabular}{|c|c|c|c|c|}
\hline Groups & $\begin{array}{c}\text { GSH } \\
(\mathrm{mg} / \mathrm{ml})\end{array}$ & $\begin{array}{c}\text { MDA } \\
(\mu \mathrm{mol} / \\
\mathrm{ml})\end{array}$ & $\begin{array}{c}\text { MDA } \\
\text { (n mol/g } \\
\text { tissue) }\end{array}$ & $\begin{array}{c}\mathrm{Zn} / \mathrm{SOD} \\
(\mu \mathrm{g} / \mathrm{ml})\end{array}$ \\
\hline Control & $31.2 \pm 0.58$ & $37 \pm 0.7$ & $40.8 \pm 0.73$ & $4.62 \pm 0.39$ \\
\hline $\mathrm{CBM}$ & $29.8 \pm 0.58$ & $\begin{array}{c}40 \pm 1 \\
c\end{array}$ & $\begin{array}{c}50 \pm 1 \\
c\end{array}$ & $4.24 \pm 0.2$ \\
\hline $\mathrm{CZn}$ & $30.8 \pm 0.37$ & $36.6 \pm 1.12$ & $\begin{array}{c}46.6 \pm 1.12 \\
\mathrm{c}\end{array}$ & $4.26 \pm 0.34$ \\
\hline $\mathrm{R}$ & $\begin{array}{c}10.8 \pm 0.58 \\
c\end{array}$ & $\begin{array}{c}62.2 \pm 0.86 \\
c\end{array}$ & $\begin{array}{c}70 \pm 1 \\
c\end{array}$ & $2.56 \pm 0.18$ \\
\hline $\mathrm{R}+\mathrm{BM}$ & $\begin{array}{c}16.2 \pm 0.86 \\
\mathrm{cr}\end{array}$ & $\begin{array}{c}46.2 \pm 1.15 \\
\mathrm{cr}\end{array}$ & $\begin{array}{c}53.2 \pm 1.46 \\
\mathrm{c} \mathrm{r}\end{array}$ & $3.26 \pm 0.23$ \\
\hline $\mathrm{R}+\mathrm{Zn}$ & $\begin{array}{c}18.4 \pm 0.51 \\
\mathrm{c} \mathrm{r}\end{array}$ & $\begin{array}{c}47.4 \pm 1.2 \\
\mathrm{c} \mathrm{r}\end{array}$ & $\begin{array}{c}57.6 \pm 1.02 \\
\mathrm{c} \mathrm{r}\end{array}$ & $\begin{array}{c}3.5 \pm 0.4 \\
\mathrm{c}\end{array}$ \\
\hline $\begin{array}{c}\mathrm{R}+\mathrm{BM} \\
+\mathrm{Zn}\end{array}$ & $\begin{array}{c}23.2 \pm 0.66 \\
\text { c r }\end{array}$ & $\begin{array}{c}43.8 \pm 1.59 \\
\text { c r }\end{array}$ & $\begin{array}{c}53.8 \pm 1.59 \\
\mathrm{c} \mathrm{r}\end{array}$ & $\begin{array}{c}3.6 \pm 0.41 \\
\mathrm{c} \mathrm{r}\end{array}$ \\
\hline
\end{tabular}

Values are expressed as mean $\pm \mathrm{SE}$.

c: Significant difference compared to control. $r$ : Significant difference compared to R group. while IL-6 level showed a significant increase. Each of treatments ameliorated irradiation effect, whereas their combination induced a significant increase in IL-2 and TNF- $\alpha$ whereas IL-6 level recorded a significant decrease compared to the irradiated group (Table 3 ).

Results presented in Table 4 demonstrated a significant decrease of blood GSH and Zn/SOD $(\mathrm{P}<0.05)$ and a significant increase $(\mathrm{P}<0.05)$ of serum and spleen MDA two weeks post exposure to $5 \mathrm{~Gy}$ gamma radiation. Protection with zinc before irradiation and BMT of rats resulted in a significant elevation of GSH and $\mathrm{Zn} / \mathrm{SOD}$ $(\mathrm{P}<0.05)$ whereas a significant decrease in serum and spleen MDA $(\mathrm{P}<0.05)$ compared to irradiated group.

\section{Discussion}

Most of cellular alteration induced by ionizing radiation is indirect and is mediated by the generation of free radicals and related reactive species, mainly derived from oxygen. Overproduction of reactive oxygen species (ROS) in cells and tissues increases oxidative stress (Nunia et al. 2007). Gamma irradiation is an immunosuppressive agent (Kajioka et al., 2000). Adaptive immune system is affected by deficient lymphopoiesis and apoptosis of lymphocytes (Wikins et al. 2002).

In the present results whole body gamma irradiation (5Gy) causes considerable decrease in the hematological values like RBC WBC and lymphocytes percentage as well as bone marrow lymphocyte, splenocytes and viable BM cells. This decrease is probably an indication of impairment of cell division and obliteration of blood-forming organs (Nunia et al., 2007) besides defective haemopoiesis (Gridley et al., 2001) in addition to their high radiosensetivity (Smart and Kumar ,2003). This is followed by thrombocytopenia and concomitant hemorrhages beside the effects in adaptive immune system resulting from apoptosis of lymphocytes and deficient lymphopoiesis (Wikins et al., 2002). Nevertheless, the decrease of RBC count might be attributed to alimentary tract injury, hemorrhage or leakage through capillary walls and/or the direct destruction of mature circulating cells (Ashry et al., 2013).

The detected decrease of splenocyte and viable BM cells which might be attributed to that irradiation kills or damages the major classes of parenchymal cells of the lymphohematopoietic

Egypt. J. Rad. Sci. Applic., Vol. 30, No.1(2017) 
system, depresses the number of the highly radiosensitive bone marrow cells (the major site of hematopoiesis) and causes atrophy of spleen (Kajioka et al., 2000).

Cytokines have been used to refer to the immunomodulating agents and play a key role in modulation of immune responses. Cytokine networks regulate lymphocyte turnover, differentiation, and activation. IL-2 is a cytokine released by Thelper lymphocytes, while (TNF- $\alpha$ ) is a proinflammatory cytokine that is synthesized by monocytes/macrophages, natural killer cells/ large granular lymphocytes, and T lymphocytes subsets (Simon, 2011). Because of irradiation influence on all these types of cells, the present study demonstrated decreased IL-2 level in irradiated animals which might be due to that spleen cells of total lymphoid irradiated (TLI) mice secrete $5-9 \%$ of the mean normal level of IL-2 (Field et al. 1997) . Gamma irradiation is known to significantly inhibit the proliferation of effective $\mathrm{T}$ cells by reducing the levels of Th1 type cytokines (such as IL-2) (Han et al., 2005). Irradiation induced a significant decrease in TNF- $\alpha$ which could be explained through supregulation of mitogen-activated protein kinase phosphatase-1 (MKP-1) in mouse macrophage (Tsukimoto et al., 2009) and its attributed to irradiation effect leading to differential regulation of T- helper cell gene expression (Seon-Kyu et al., 2002). IL-6 levels showed a significant increase post irradiation which was attributed by Chang et al. (1997) to that ionizing radiation induced DNA damage has been shown to initiate the expression of various circulatory cytokines such as IL-6 and some of these responses may be related to apoptosis. IL-6 itself is a pluripotent cytokine which is involved in acute pro-inflammatory process associated with overexposure to ionizing radiation (Petit-Frère et al., 2000).

The present results demonstrated a significant reduction in blood GSH, SOD activity and parallel elevation in serum and spleen MDA post irradiation which could be attributed to enhanced utilization of the antioxidant system in an attempt to detoxify radiation generated free radicals (Krishna and Kumar, 2005). The decrease in the activity of antioxidant enzymes might result from radiation-induced cell membrane damage and alterations in dynamic permeability of membranes due to peroxidation. Damage of plasma membranes, which contain high percentage of polyunsaturated fatty acids, is followed by the release of intracellular enzymes to the blood stream (Saada et al., 2003).

The present results discerned that BMT alone lead to a significant elevation in RBCs, WBCs as compared to the control group after 14 days which comes in accordance with Nunia et al. (2007). BMT post irradiation showed significant elevation of RBC, lymphocytes and BM viable cells which might be attributed to the accelerated restoration of remaining functional hematopoietic cells that is believed to be the major factor in the survival of irradiated mice (Berdan et al., 2011 and Meng et al., 2013). Survival after irradiation actually results from the recovery of several target systems, such as the bone marrow, gastrointestinal tract, skin and hemostatic systems (Widel et al., 2003). Splenocyte elevation after irradiation is attributed to that recovery was dependent on extramedullary cell division in the thymus and spleen (Abu-Sinna et al., 2005).

In the present study, BMT to irradiated animals induced a slight reduction in IL-2 concentration compared to irradiated animals. Wang (2002) explained that IL-2 concentrations in recipient mouse serum were relatively low, because of cytokine autocrine and paracrine physiological characteristics, their expression in a microenvironment may be sufficient to reconstitute the immunological and hematopoietic depression after BMT. Also, BMT could cause the lack of IL 2-producing cells and/or the increased activity of suppressor cells of the helper function. The depression in IL-2 level in the present results support the successful engraftment of bone marrow cells (Nakamura et al., 2004). The decrease of IL-6 after BMT to irradiated rats compared to the increased level in irradiated group could be due to that IL- 6 might mitigate acute GVHD without losing the significant antitumor benefits of allogeneic BMT (Tawara et al., 2010) thus might support the successful engraftment of bone marrow cells. Amelioration of serum TNF- $\alpha$ levels of irradiated rats after BMT may be related to absence of the immunological reaction against non-HLA allogeneic antigens as a result of the immunosuppressive effect of irradiation. Furthermore, neutralization of TNF- $\alpha$ have been reported by Brown and Thiele (2000) to reduce complications after BMT. It is well documented that total body irradiation followed by BMT, has been shown to raise the erythropoietic activity 
in both bone marrow and spleen (De Rooij et al. 2002). The elevation in red blood cells, the important source of GSH, can ameliorate the GSH depletion in blood and organs and hence decrease oxidative stress (Ashry et al, 2009).

In the present study zinc sulphate $(10 \mathrm{mg} / \mathrm{Kg}$ body weight) supplementation before irradiation significantly improved bone marrow lymphocytes and viability which was attributed by ( Rink and Gabriel, 2000) to that the zinc deficient organism shows impaired functions in all kinds of immune cells in vivo. Zinc supplementation causes a significant elevation in splenocyte cells after gamma irradiation, is probably the consequence of enforcing the immune response via reduced apoptosis of splenocytes. These changes were probably caused by increased synthesis of HSP-70 by splenocytes, which might enhance survival of mice with LPS-induced endotoxemia (Unoshima et al., 2001).

Baltaci et al. (2003) recorded that zinc supplementation has a positive influence on hematological parameters which comes in accordance with the detected elevation of RBC, WBC and lymphocytes. Zinc substrates are recommended as radioprotectors as well as for treatment of radiation hazards (Hanan et al., 2007).

In the current study, there was a significant elevation of IL-2 and TNF- $\alpha$ in irradiated rats treated with zinc sulphat. This is explained by that zinc plays a role in cytokine production. Prasad (2008) and Rahfiludin et al.( 2013) indicated that TNF- $\alpha$ and. IL-2 production is improved when zinc level is maintained by giving zinc supplement. In a study by Yalçın et al. (2011), zinc supplementation had a beneficial effect on immune response and increased serum TNF- $\alpha$ level after irradiation In this study zinc supplementation before irradiation showed a reduction in serum levels of IL-6. Wellinghausen et al. (1997) observed that zinc affects a functional activation or inhibition of isolated immune cells and also appears to influence cell growth and cytokine production and is used for treatment of radiotherapy caused dermatitis (Alterio et al., 2007).

Zinc supplementation has documented a significant increase in GSH level in irradiated rats, which might be due to that zinc protects sulfhydryl groups from oxidation induced by gamma irradiation( Bray and Bettger 1990). The data showed that there was a decrease of serum and spleen tissue MDA level in $\mathrm{Zn}$ supplemented groups treated with gamma irradiation. The generation of oxidative burst were impaired by decreased zinc levels (Keen and Gershwin, 1990). Zinc supplementation to irradiated treated rats, significantly attenuated the adverse effects caused by gamma irradiation on the levels of MDA, GSH and SOD. There are significant oxidant/antioxidant changes in RBC following irradiation in rats, while zinc was shown to act as a radioprotective agent (Dani and Dhawan, 2006). The previous study showed that zinc supplementation increased the activity of Zn SOD in blood. Zinc sulphate could modulate apoptosis of thymocytes induced by glucocorticoid; the mechanism might involve the exchange of intracellular calcium, the redox of cells, and the forms of zinc might go different ways in the regulations (Ze-peng et al., 2005). Dietary zinc exerts its beneficial effects on growth performance in irradiated rats through increasing serum $\mathrm{Zn}$ SOD levels (Wang et al., 2012).

Zinc sulphate was found to protect BMT that was reflected upon accelerated haematopoeitic reconstitution, decreased oxidative stress and enhanced immune response.

\section{Conclusion}

The present findings support the protective role of zinc sulphate administration against the severity of radiation induced disturbance via enforcing allogenic bone marrow transplantation and the immune response.

\section{References}

Abu-Sinna, G., Kafafy, Y.A., Nassar, A.Y. Salman M.A. (2005) Synergistic effect of bone marrow transplantation and bradykinin potentiating factor isolated from venom on thymus and spleen of sublethally irradiated guinea pig. Egypt. J. Rad.Sci. Applic., 18: 249-255.

Ali, H.F., Fddah, L.M., Rizk, M.Z. and El Ebiary, H. (2007) Role of anserine and/or zinc in modulating nucleic acid and protein disorders in rats exposed to gamma irradiation. J. Pharmacol. Toxicol., 2: 1-19.

Alterio, D., Jereczek-Fossa, B.A., FioreMR, Piperno

Egypt. J. Rad. Sci. Applic., Vol. 30, No.1(2017) 
G, Ansarin M and Orecchia, R. (2007) Cancer treatment-induced oral mucositis. Anticancer Research 27:1105-1126.

Aramachi, T. (1989) Immuno-Biological Laboratories Company, Ltd. Japan 370: 831.

Ashry, O.M., Hussein, E.M. and Salama S F. (2009) Boosting of antioxidant defence by Interferon Alfa in irradiated bone marrow transplanted rats. Egypt J.Rad. Sci. Applic. 22 :19-33.

Ashry, O.M., Soliman, M.G., Mahmoud N.H. and Abou Mossalam, M. (2013) Immunostimulatory Role of Panax Ginseng in Irradiated Bone Marrow Transplanted Rats. Int. J. Acad Res. 5: 115-123.

Azab, K.S., Zahran, A.M. Noaman, E. (2004) Role of zinc cysteine in the regulation of metallothionein induction in whole body $\gamma$ irradiated rats. Egypt J. Rad. Sci. Applic., 7: 213-223.

Augustine, A.D., Gondre'-Lewis, T., McBride, W., Miller L, Pellmarc TC, Rockwelld S. 2005. Animal Models for Radiation Injury, Protection and Therapy. Rad. Res. 164:100-109.

Baltaci, A.K., Ozyurek, K., Mogulkoc, R., Kurtoglu, E., Oztekin and E. Kul, A. (2003) Effects of zinc deficiency and supplementation on some hematologic parameters of rats performing acute swimming exercise. Acta. Physiol. Hung 90: 125-132.

Berdan, S., Nguyen A. and Hassanein, D. (2011) Robo 4 cooperates with cxcr4 to specify hematopoietic stem cell localization to bone marrow niches. Immunol 8: 72-83.

Beutler, E., Duron, O. and Kelly, B.M. (1963) Improved method of the determination of blood glutathione. J. Lab. Clin. Med., 61: 882-888.

Bray, T. M. and Bettger, W.J. (1990) The physiological role of zinc as antioxidant. Free Radical Biol. Med., 8: 281-291.

Brown, G.R. and Thiele, D.L. (2000) Enhancement of MHC class I-stimulated alloresponses by TNF/ TNF receptor (TNFR) 1 interactions and of MHC class II-stimulated alloresponses by TNF/TNFR2 interactions. Eur. J. Immunol., 30: 2900-2907.
Chan, V.S. and Perlstein, L.D. (1987) "Affinity Chromatographic Separation of AlphaFetoprotein Variants." Academic Press, New York p. 71.

Chang, C.M., Limanni, A., Baker, W.H., Dobson, M., E, Kalinich, J.F. and Patchen, M.L. (1997)Sublethal gamma irradiation increases IL-1alpha, IL-6, and TNF-alpha mRNA levels in murine hematopoietic tissues. J. Interferon. Cytokine. Res. 17:567-572.

Chen,T., Burke, K .A .K., Zhan,Y., Wang, X. Shibata, D. and Zhao, Yi. (2007) IL-12 Facilitates both the recovery of endogenous hematopoiesis and the engraftment of stem cells after ionizing radiation. Exp. Hematol. 35, 203.

Dacie, S.T. and Lewis, S.M. (1993) Practical Haematology. ELBS and Churchill, Levingston. London, Chapt., 5: 37-47.

Dani, V. and Dhawan, D. (2006) Zinc as an antiperoxidative agent following iodine-131 induced changes on the antioxidant system and on the morphology of red blood cells in rats. Hellenic . J. Nucl. Med., 9: 22-26.

De Rooij, D.G., Van de Kant, H.J, Dol R., Wagemaker, G. and Van Buul, P.P. (2002) Longterm effects of irradiation before adulthood on reproductive function in the male Rhesus monkey. Biol.Reprod., 66: 486-502.

Esser, M.T., Bess, J.W., Suryanarayana, K., Chertova, E., Marti, D., Carrington, M., Arthur, L.O. and Lifson, J.D. (2001) Partial activation and induction of apoptosis in CD4+ and CD8+ $\mathrm{T}$ lymphocytes by conformationally authentic noninfectious human immunodeficiency virus type 1. J.Virol., 75: 1152-1164.

Field, E.H., Rouse, T.M., Gao, Q. and Chang, B. (1997) Association between enhanced Th2/Th1 cytokine profile and donor T-cell chimerism following total lymphoid irradiation.Hum Immunol, 52: 144-154.

Gérard, S. (2001). Busulfan plus cyclophosphamide compared with total body irradiation plus cyclophosphamide before marrow transplantation for myeloid leukemia: long term following-up of randomized studies. J. Blood. 98: 3569-3574.

Gridley, D.S., Pecaut, M.J., Miller, G.M., Moyers, M. F. and Nelson, G.A. (2001) Dose and doseEgypt. J. Rad. Sci. Applic., Vol. 30, No.1(2017) 
rate effects of whole body gamma irradiation: II. Haematological variables and cytokines. $J$. Immunol.,15: 209-219.

Haase, H. and Rink, L. (2009) The immune system and the impact of zinc during aging. Immun Ageing 12: 6-9.

Han, S.K., Song, J.Y., Yun, Y.S. and Yi, S.Y. (2005) Gamma irradiation reduced IFN-gamma expression, STAT-1 signal, and cell-mediated immunity. J. Biochem. Mol. Biol., 35: 583-589.

Harfouche, G. and Martin, M.T. (2010) Response of normal stem cells to ionizing radiation: A balance between homeostasis and genomic stability. Rev. Mut. Res. 704: 167-74.

Kajioka, E.H., Andres, M.L., Li, J., Mao, X.W., Moyers, M.F., Nelson, G.A., Slatter, J,M. and Gridly, D.S. (2000) Acute effects of whole body proton irradiation on the immune system of mouse. Rad. Res., 14:153-187.

Kaminska, J., Kowalska, M.M., Nowacki, M.P., Chwalinski, M.G., Rysinska, A. and Fuksiewicz, M. (2000) CRP, TNF, IL-1ra, IL-6, IL-8 and IL10 in blood serum of colorectal cancer patients. Pathol. Oncol. Res. 6: 38-41.

Keen, C.L, and Gershwin, M.E. (1990) Zinc deficiency and immune function. Ann. Rev. Nutr., 10: 415-431.

Krishna, A. and Kumar, A. (2005) Evaluation of radioprotective effect of Rajira (Amaranthus paniculatus) extract in Swiss albino mice. Rad. Res., 46: 233-246.

Meng, J., Meng, Y., Liang, Z., Du, L., Zhang, Z., Hu, $X$. and Shan, F. (2013) Phenotypic and functional analysis of the modification of murine bone marrow dendritic cells (BMDCs) induced by neutral ginsing polysaccharides (NGP). J.Human vaccine and immunotherap.9:233-241.

Nakamura, T, Good, R.A., Yasumizu, R., Inoue, S., Oo, M.M.., Mamashima, Y. and Ikehara, S. (2004) Successful liver allografts in mice by combination with allogenic bone marrow transplantation. J Proc Natl Acad Sci 12: 4529-4532.

Nunia, V., Sncheti, G. and Goyal, P.K. (2007) Protection of Swiss albino mice against wholebody gamma irradiation by diltiazem. Brit. J. of Radiol. 80: 77-84.
Petit-Frère, C., Capulas, E, Lyon, D., Norbury, C., Lowe, J., Clingen, P., Christopher, J. and Green, M. (2000) Apoptosis and cytokine release induced by ionizing or ultraviolet $\mathrm{B}$ radiation in primary and immortalized human keratinocytes. Carcinogen 21: 1087-1095

Pourhomayoun, M., Fowler, M.L. and Jin, Z. (2014) Robustness Analysis of Sparsity Based Tumor Localization under Tissue Configuration Uncertainty. IEEE Signal Processing in Medicine and Biology Symposium (SPMB12) 3: 8-15.

Prasad, A.S. (2008) Clinical, immunological, antiinflammatory and antioxidant roles of zinc. Exp. Gerontol., 43: 370-377.

Rahfiludin, M., Wirjatmadi, B., Agusni, I. and Dahlan, Y. (2011) Zinc supplementation could modulate $\mathrm{T}$ cell to maintain interleukin-2 level in seropositive contact of leprosy patients. Med. J. Indones., 20: 201-204.

Rink, L. and Gabriel, P . (2000) Zinc and the immune system. Proc. Nutr. Soc., 59: 541-552.

Roosen, N., Doz, F., Yeomansk, K. and Rosenblum, M. (1994) Effect of pharmacological doses of zinc on the therapeutic index of brain tumor chemotherapy with carmostine. Cancer Chemother. Pharmacol., 34: 385-392.

Saada, H.N., Said, U.Z. and Mahdy, A. M. (2003) Effectiveness of Aloe Vera on the antioxidant status of different tissues in irradiated rats. Pharmazie $\mathbf{5 8}$ : 929-931.

Seon-Kyu, H., Jie-Young, S., Yeon-Sook, Y., SehYoon, Y. (2002) Gamma Irradiation-reduced IFN-g Expression, STAT1 Signals, and Cell-mediated Immunity. J. Biochem. Mol. Biol. 35: 583-589.

Simon, F. (2011) Immunomodulatory cytokines: directing and controlling immune activation. Arthritis Research \& Therapy 13(2): 1-14.

Sinai, M.R., Uma Devi, S. and Yadav, S.S. (1978) Radiation protection of bone marrow lymphocytes by 2-Mercaptoprpionylglycine (MPG). Rad. Res. 15: $1627-1643$.

Singh, D.K., Li , L. and Porter, T.D. (2006) Policosanol inhibits cholesterol synthesis in hepatoma cells by activation of AMP-kinase. $J$.

Egypt. J. Rad. Sci. Applic., Vol. 30, No.1(2017) 
Pharmacol. Exp. Ther., 318:1020.

Smart, R.M. and Kumar, A. (2003) Radioprotection of swiss albino mice by plant extract Mentha piperita (Linn). J. Radiat. Res., 44: 101.

Sredini, B., Albeck, M., Kazimmersky, G. and Shalet, F. (1992) The immunomodulator administrated orally as a radioprotective agent. $J$. Immunopharmacol.14: 612-622.

Steel, R.G.D. and Torrie, J.H. (1980) Analysis of covariance. In: Principles and Procedures of Statistics: A Biometrical. Approach. 5: 401-437.

Sun, J.Y., Jing, M.Y., Weng, X.Y., Fu, L.J., Xu, Z.R., Zi, N.T. and Wang, J.F. (2005) Effects of dietary zinc levels on the activities of enzymes, weights of organs, and the concentrations of zinc and copper in growing rats. Biol. Trace. Ele. Res., 107: 153-166.

Takabatake, T., Nakamoto, G. and Menovsky, A.A. (1997) Strong reduction of quasiparticle scattering rate with gap formation in CeNiSn. Phys. Rev., 56: 8277-8281.

Tawara, I., Koyama, M. and Liu, C. (2010) Interleukin-6 modulates graft-versus-host responses after experimental allogeneic bone marrow transplantation. Clin. Cancer. Res., 17: 77-88.

Tsukimoto, M., Homma, T., Mutou, Y. and Kojima, S. (2009) 0.5Gy gamma radiation suppresses production of TNF-alpha through up-regulation of MKP-1 in mouse macrophage RAW264.7 cells. Rad. Res., 17: 219-224.

Unoshima, M., Nishizono, A., Takita-Sonoda, Y., Iwasaka. H. and Noguchi, T. (2001) Effects of zinc acetate on splenocytes of endotoxemic mice: enhanced immune response, reduced apoptosis, and increased expression of heat shock protein 70 . J. Lab. Clin. Med. 137: 28-37.

Wang, M.Q., Tao, W.J., Ye, S.S., Du, Y.J., Wang, C.A. and Shen, S.X. (2012) Effects of dietary pharmacological zinc on growth, liver metallothionein, $\mathrm{Cu}, \mathrm{Zn}$-SOD concentration and serum parameters in piglets. J. Animal. Vet. Advances.,11: 1390-1394.

Wang, Q. (2002) Determination of doxycycline in serum by high-performance liquid chromatography. Chin J. Clin. Phamacol., 3: 119-201.
Wellinghausen, N., Martin, M. and Rink, L. (1997) Zinc inhibits interleukin- 1-dependent $\mathrm{T}$ cell. stimulation. Eur. J. Immunol, 27: 2529-2535.

Widel, M., Jedrus, S., Lukaszczyk, B. and Zwierzycka, K. and Swierniak A. (2003) Radiation induced micronucleus frequency in peripheral blood lymphocytes is correlated with normal tissue damage in patients with cervical carcinoma undergoing radiotherapy. Radiat. Res., 159: 713-721.

Wikins, R.C., Wikinson,D., Maharaj, H.P., Bellier, P.V., Cybulski, M.B. and McLean, J.R. (2002) Differential apoptotic response to ionizing radiation in subpopulations of human white blood cells. Mutat Res., 513: 27-40.

Yalçın, S.S., Engür-Karasimav, D., Alehan, D., Yurdakök, K., Ozkutlu, S. and Coşkun, T. (2011) Zinc supplementation and TNF- $\alpha$ levels in vaccinated cardiac patients. $J$ Trace Elem Med Biol 25: 85-90.

Youn, Yi, J., Jin, Jang, Y., Shim, Choi, S. and Chung, E. (2010) TNF-alpha down regulates E-cadherin and Sensitizes Response to $\gamma$-irradiation in Caco-2 Cells. Cancer Res. Treat. 41, 164-170.

Yoshioka, T., Kawada, K., Shimada, T. and Mori, M. (1979) Lipid peroxidation in maternal cord blood and protective mechanism against activated oxygen toxicity in blood. Am. J. Obstet. Gynecol., 135: 372-377.

Ze-Peng, Y., Guo-Wei, L., Hong-Yu, H., Yun-Yu, W. and Yong-Hui, S. (2005) Effect of different zinc sources and levels on inhibition of the apoptosis induced by glucocorticoid of thymocytes in vitro. Biol.Trace. Elem. Res., 105: 215-227.

Received 31/1/2017 accepted 5/8/2017

Egypt. J. Rad. Sci. Applic., Vol. 30, No.1(2017) 


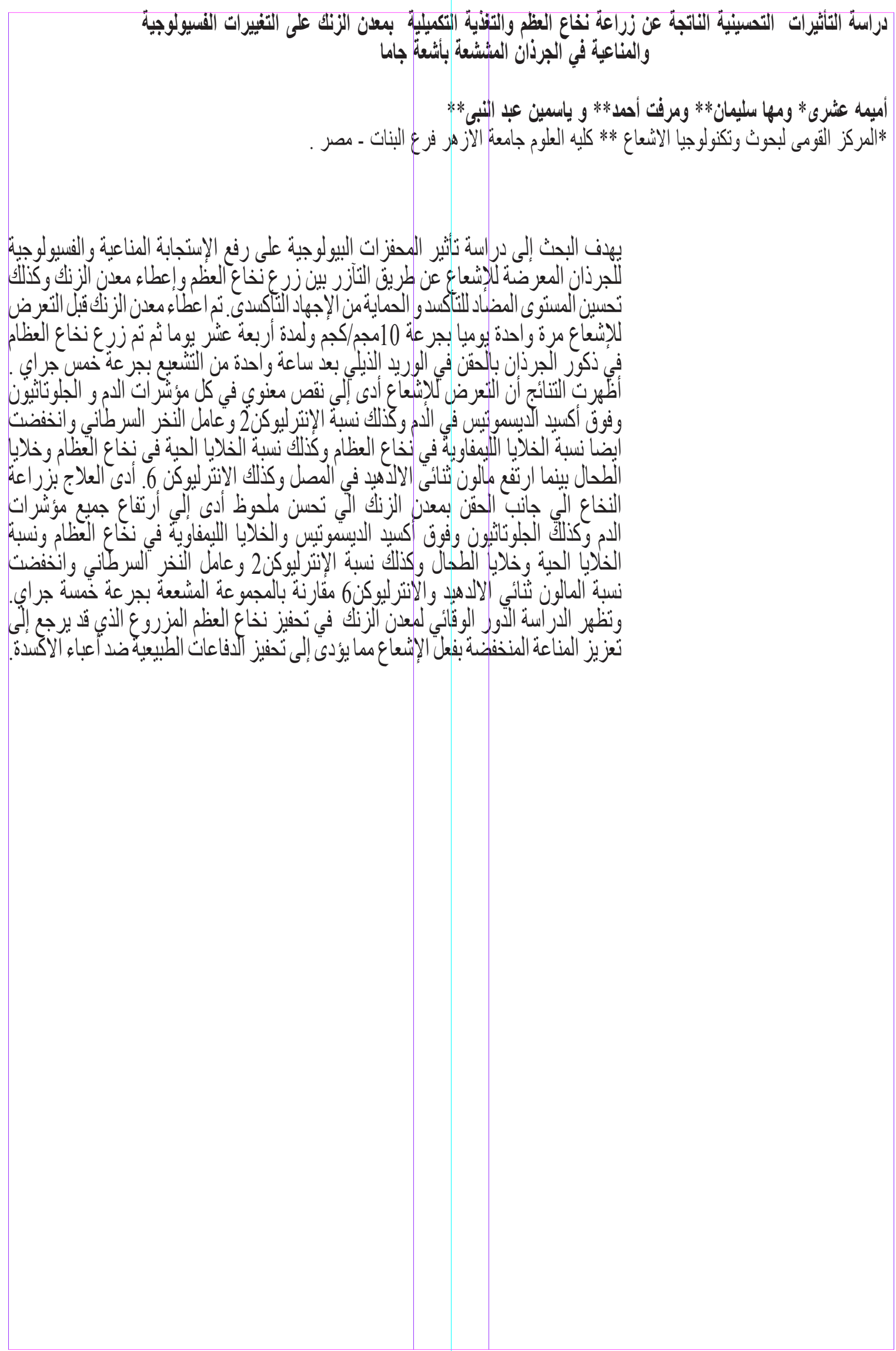

